United States. It is regrettable that it has not yet been restored to its owners. There must be feasible ways of securing the payment of the American claims, without violating our national traditions. For example, it has not been made clear why we cannot share, to the limited extent required, in the payments to be effected by Germany under the Dawes Report. It would seem that the United States should be able to obtain the consent of the Allies to permit Germany to pay us the moderate sums involved, without participating in "sanctions." Payment and enforcement are separable. Even payment by Congress of the American claims against long-term German bonds would be preferable to touching the private sequestrated property. Simple respect for our past and a prudent regard for our future, dictate that we cannot, as an inviting and investing nation, jeopardize the security of foreign private property, both of aliens in the United States and of Americans abroad, by the adoption of so destructive and shortsighted a policy as the confiscation of private property for the discharge of a public indebtedness. In the words of Hamilton, it "would disgrace the Government of the country and injure its true interests."

Some comfort may be derived from the profound words of John Bassett Moore who, as chairman of the Commission of Jurists to consider and report upon the revision of the rules of warfare, said, in opening the conference at the Hague in December, 1922:

I deem it to be inconceivable that a generation accustomed to boast that it is the heir of all the ages, in the foremost files of time, should consciously relinquish the conception that all human affairs, in war as well as in peace, must be regulated by law, and abandon itself to the desperate conclusion that the sense of self-restraint, which is the consummate product and the essence of civilization, has finally succumbed to the passion for unregulated and indiscriminate violence.

EdWIN M. Borchard.

\title{
THE INDIVIDUAL AND INTERNATIONAL LAW
}

Philosophy and law have suffered much harm because of the desire of men for rigid classification and definition. There is a naive yearning to circumscribe carefully a subject and to place it safely within the confines of a letter-file. Men insist on simplicity in their thinking: they abhor the complex and the uncertain. As a wise Frenchman once observed, "One defines a subject in order to avoid the necessity of understanding it."

The law of nations has been thus treated: it has been narrowly restricted and rigidly defined. Various assertions of principles have been so boldly affirmed and reiterated by successive publicists that they have become almost axiomatic. An Attorney-General or a Secretary of State declares that the three-mile limit of maritime jurisdiction has been universally fixed, 
and the Supreme Court solemnly insists that this is true though unable to define what is meant by "territorial waters." It is enough to say that the matter has been settled: rigidity in the law is to be preferred to reason.

No proposition perhaps has received such general assent as that international law applies only between states, and that a man has no international rights. By this method of definition and classification the publicists often attempt to relegate international private law to the sphere of "conflict of laws," to employ the Anglo-American phraseology. Problems of domicile, of personal status, and of nationality itself, that inevitably give rise at times to diplomatic controversy, are ignored. The facts of international society must be made to conform to the categories of the publicists. According to their concept, the law of nations is the dictator, the moralist, the preacher, the rigid mould into which the interests and rights of men must be poured.

Now it would not seem very difficult to demonstrate in a simple way that the proposition that man is the "object" of law with no other rights than flow from his nationality is unsound both in principle and practical experience. A pirate is the enemy of all mankind. He may be summarily executed without any thought concerning his nationality. A slave bound in chains is entitled to his freedom the world over. No one for a moment. would think to ask what his political allegiance might be. Piracy and slavery are both proscribed by the law of nations. The question of national classification is in no way involved.

The case of the Paquette Habana and of the Lola, small fishing vessels: owned by Spanish nationals and captured during the war in 1898 by American gunboats, is very pertinent in this connection. The Supreme Court of the United States held:

This review of the precedents and the authorities on the subject appears to us abundantly to demonstrate that at the present day, by the general consent of the civilized nations of the world, and independently of any express treaty or other public act, it is an established rule of international law, founded on considerations of humanity to a poor and industrious order of men, and of the mutual convenience of belligerent states, that coast fishing vessels, with their implements and supplies, cargoes and crews, unarmed and honestly pursuing their peaceful calling of catching and bringing in fresh fish, are exempt from capture as prize of war. ${ }^{1}$

It is of peculiar interest to note that here was a case where no treaty or positive international engagement was involved; where no interposition by the Spanish Government in behalf of the owners of these vessels was permissible or necessary. The court recognized their individual right to plead their own cause. By the law of nations their rights as individuals without respect to their national affiliations were completely recognized, and their vessels were restored.

Still other instances might be cited, but these three concerning pirates, 1177 U. S. 677, quoted in Cases in International Law, by Scott, p. 12. 
slaves, and fishermen may serve to illustrate the falsity in actual experience of the assertion of publicists that men are merely the "objects" of international law, and that, like straying cattle, they have no other rights than what their owners may be able to establish in their behalf! It is enough for our immediate purpose to note these serious breaches in the circumvallation or fragile screen erected by some of the authorities in international law.

The question that naturally, and somewhat impatiently, arises is: How did such a theory concerning the rights of the individual ever originate and find such strong credence? The answer would seem clearly to be found in the speculations of certain of the early political theorists concerning sovereignty, notably of Bodin, who thought in terms of supreme power. Grotius, though somewhat vague in his political theorizing on this subject, evidently regarded sovereignty as supreme political power (potestas civilis), which he identified on the whole with the person of ruling kings and princes. They expressed towards all other monarchs the interests and rights of sovereign states, whether territorial or human. Any other conception of the law of nations conceding to individuals definite rights of their own would have been confusing and inadmissible at a time when men possessed their belongings and their lives only on the sufferance of their sovereign lords. The concept of men under a "social compact" as free sovereign lords, from whom all sovereignty was derived, was necessarily slow in forming and in gaining acceptance. Not till the nineteenth and the twentieth centuries did the idea of a truly democratic state, based on the interests and the rights of the individual, emerge triumphantly. Today the doctrine of "selfdetermination" is sweeping away (perhaps in a dangerous manner) the archaic remains of personal sovereignty. Men everywhere are beginning to realize the truth that the state exists, not as an end in itself, but as the means to their own individual welfare and happiness. Political institutions are being subjected to severe tests. The administration of justice is increasingly difficult and fails to command complete popular confidence. Law itself is being subjected to the most critical analysis. Men are demanding that it should be based on principles of common sense to serve adequately the changing needs of men in all the varied fields of international intercourse.

The time would now seem to have arrived for a thorough reappraisal and revision of the principles of the law of nations in order to regulate properly all the complicated relationships in international society and to facilitate justice within the family of nations. The democratic principle must be logically applied to international affairs as well as to domestic. The conception of a sovereign state from which all rights flow must give way to the conception that international law itself derives its ultimate sanction and respect from the sovereign people. The "rights of man" must be fully and practically recognized in his pursuit of a livelihood, and of the gratification of his legitimate intellectual and spiritual aspirations throughout the world.

The alien, and even the heimatlos, no longer accepts the old Roman maxim 
that "a strange air makes a man unfree." He believes that, whether as a member of a community whose right to existence, independence, and to intercourse has been duly recognized, or as a constituent member of international society as a whole, he has certain basic, inalienable rights that must be respected, notably of his own person, of property, of livelihood, of thought, of conscience, and of justice in general. He insists that international common law now concedes definite standards of rights and obligations in all these respects which no "civilized" community may be permitted to disregard. He believes in the right to appeal to any tribunal, domestic or international, for the protection of these rights.

The fact that the government of the state to which a man may own allegiance declines for reasons of expediency, policy, or otherwise to champion his rights in no way implies that he possesses none. He may have no agent to look after his interests; he may be unable to employ the ablest legal advocates: the law still exists for the very purpose of protecting his rights. The tribunals are open to him and the judges are there to see that justice is administered irrespective of his backing.

We have been wofully misled by this archaic theory of men as mere "objects" of law. We have exalted governments as if they were the fount and source of the rights of man. With rare exceptions, governments are no longer sovereign: they are the agents and representatives of sovereign citizens whose interests they must zealously serve. Scattered throughout international society are diplomats and consuls to assist their fellow citizens in a multitude of ways. Their rights, however, should never be made to depend upon the courtesy, the judgment, the whims, or prejudices of any officials, whether diplomatic or otherwise. The courts should everywhere be open to all law-abiding men. The very Court of International Justice at The Hague must ultimately be opened to the free access of all who may be denied justice in the courts of any territorial jurisdiction. Special international tribunals, undoubtedly, by reason of practical exigencies, will have to be created to deal with such matters as pecuniary claims where the principle of liability is admitted, or with technical questions arising in the vast field of international private law.

And the law itself in many uncharted depths and shallows, particularly concerning the responsibility of states for torts, or for contractual claims, must be formulated definitely and comprehensively. This can best be done through such international conferences as were recommended by the Commission of Jurists that drew up the Statute for the Permanent Court of International Justice. It may not be permitted to depend upon the arbitrary judgment of national governments, nor should any denial of justice be allowed because of the absence of controlling principles and rules. It should not depend upon the idiosyncrasies of any judge or group of judges seeking to create principles out of their own inner consciousness.

Governments are the proper agencies for formal international intercourse 
and may accomplish great things for the advancement of the interests and welfare of all mankind. They must remember, however, that they are not the source of rights. Their justification for existence throughout international society consists in the success with which they aid men in the pursuit of happiness and in the perfection of those relations which it is the object of the law of nations to foster and safeguard.

\section{Philip Marshall Brown.}

\section{OPINION OF COMMISSION OF JURISTS ON JANINA-CORFU AFFAIR}

The controversy between Greece and Italy over the assassination of the Italian General Tellini and other officials of the international boundary commission, at Janina, near the Albania border of Greece, and the subsequent occupation of Corfu by Italian forces, was settled by agreement of the parties through the mediation of the League of Nations and the Conference of Ambassadors in September, 1923. ${ }^{1}$ The fact, however, that the settlement was reached through acceptance by the parties of the decision of the Conference of Ambassadors at Paris meant that it gave no definite answer to the various legal contentions advanced during the discussion in the League Council. These contentions involved interpretations of the Covenant and points of general international law of unusual interest. It is therefore gratifying that after settlement of the controversy they were submitted to a commission of jurists as abstract questions. This commission, selected by the states represented on the Council of the League, reported on March 13 to the Council, which unanimously approved the report, though representatives of Sweden and Uruguay thought that the answer given to the fourth question was not as explicit as desirable in distinguishing the cases in which coercive measures were and were not legitimate. ${ }^{2}$

The problems with which the Commission of Jurists dealt arose out of (1) the contention of Italy that "any discussion or any step taken by the League of Nations (in the Janina-Corfu affair) would be out of place owing to its clear incompetence" $;^{3}$ (2) the contention of Greece that the Italian occupation of Corfu was "outside the terms of the Covenant," " and (3) the assertion by the Conference of Ambassadors that "it is a principle of international law that States are responsible for political crimes and outrages committed within their territory." 5 The first two problems involved an

${ }^{1}$ See editorial comments, this Journal, Vol. 18, pp. 98-108.

2 Monthly Summary of the League of Nations, Vol. 4, pp. 53-54, April, 1924.

3 Minutes of the 26th Session of the Council, League of Nations, Official Journal, Vol. 4, p. 1287, November, 1923.

4 Ibid., p. 1281. See also p. 1277.

' Ibid., p. 1294. See also statement of M. Politis of Greece, p. 1288, and of M. Hanotaux of France, p. 1297. 